\title{
15. GEOCHEMICAL STUDIES OF SEDIMENT AND INTERSTITIAL WATER, SITES 248 AND 249, LEG 25, DEEP SEA DRILLING PROJECT
}

\author{
Vesna Marchig, Bundesanstalt für Bodenforschung, Hannover, Germany \\ and \\ T. L. Vallier, Scripps Institution of Oceanography, La Jolla, California
}

\begin{abstract}
Supplementary geochemical studies were made on samples from Sites 248 and 249 in the southwestern Indian Ocean. Three groups of chemical analyses were carried out in the following order: (1) analysis of interstitial waters $\left(\mathrm{Na}, \mathrm{K}, \mathrm{Mg}, \mathrm{Ca}, \mathrm{Cl}, \mathrm{SO}_{4}\right)$; (2) analysis of carbonate fractions $(\mathrm{Ca}, \mathrm{Sr}, \mathrm{Mg}, \mathrm{Fe}, \mathrm{Mn})$; and (3) analysis of the insoluble residue after extraction of the carbonate ( $\mathrm{Si}, \mathrm{Ti}, \mathrm{Fe}, \mathrm{Mn}, \mathrm{Cu}, \mathrm{Zn}, \mathrm{Mg}, \mathrm{Ca}, \mathrm{Ni}, \mathrm{Co}, \mathrm{Mo}, \mathrm{V}, \mathrm{B}, \mathrm{Cr}$ ). In addition to the chemical analyses, quartz, lussatite, and opaline were determined by X-ray diffraction.

There are relationships between changes in sediment and interstitial water chemistries relative to depth. The original nature of the sediment seems to be the most important factor influencing its chemistry. Some chemical changes can occur during the diagenesis of carbonates, such as $\mathrm{Mg}$ enrichment and $\mathrm{Sr}$ depletion. The Eh conditions and their changes can influence the chemistry of the sediments by the formation of sulfides or the mobilization of $\mathrm{Mn}$. Changes in the chemistry of interstitial waters are mostly related to diagenetic changes within the sediment such as the formation of dolomite, palygorskite, and clinoptilolite, and possible absorption of $\mathrm{Sr}$ in clay mineral lattices.
\end{abstract}

\section{INTRODUCTION}

Sites 248 and 249 , in the southwestern Indian Ocean (Figure 1), were selected for additional geochemical studies. The purpose of these studies was to determine the relationships between changes in the chemical composition of interstitial water and changes in the chemical composition of sediment with changes in depth in these two holes. Even though the sites are close geographically, they are greatly different in their sediment histories. Five facies are represented in these two holes. At Site 248, they include a terrigenous, volcanic clay, and brown clay facies, and at Site 249, they include a nanno ooze/chalk and a claystone facies. All three facies at Site 248 apparently were deposited near or below the calcium carbonate compensation depth (CCD). At Site 249, both facies were deposited above the CCD, although the lower one accumulated in a reducing, euxinic environment.

Site 248 is located in the western part of the Mozambique Basin with a depth of 4994 meters of water. The hole was drilled to a depth of 434 meters below the sea floor ( $422 \mathrm{~m}$ of sediment and $12 \mathrm{~m}$ of basalt), and 17 cores were attempted. These yielded 37.2 meters of sediment and 3.6 meters of basalt. Site 249 is located on the Mozambique Ridge, about $130 \mathrm{~km}$ west of Site 248 , with a depth of 2088 meters of water. The hole was drilled to a depth of 412 meters ( $408 \mathrm{~m}$ of sediment and $4 \mathrm{~m}$ of basalt) below the sea floor. Thirty-three cores were attempted, which led to the recovery of 218.8 meters of sediment and 2.6 meters of basalt.

\section{METHODS}

Twenty samples were taken aboard the Glomar Challenger: six from Site 248 and 14 from Site 249. Three groups of analyses, carried out at the Bundesanstalt für Bodenforschung under the direction of the senior author, included: (1) analysis of interstitial waters $(\mathrm{Na}, \mathrm{K}, \mathrm{Mg}, \mathrm{Ca}$, $\mathrm{Sr}, \mathrm{Cl}$, and $\left.\mathrm{SO}_{4}\right) ;(2)$ analysis of carbonate fractions $(\mathrm{Ca}, \mathrm{Sr}$, $\mathrm{Mg}, \mathrm{Fe}$, and $\mathrm{Mn}$ ); and (3) analysis of the "noncarbonate," i.e., the insoluble residue after extraction of the carbonate ( $\mathrm{Si}, \mathrm{Ti}, \mathrm{Fe}, \mathrm{Mn}, \mathrm{Cu}, \mathrm{Zn}, \mathrm{Mg}, \mathrm{Ca}, \mathrm{Ni}, \mathrm{Co}, \mathrm{Mo}, \mathrm{V}, \mathrm{B}$, and $\mathrm{Cr}$ ).

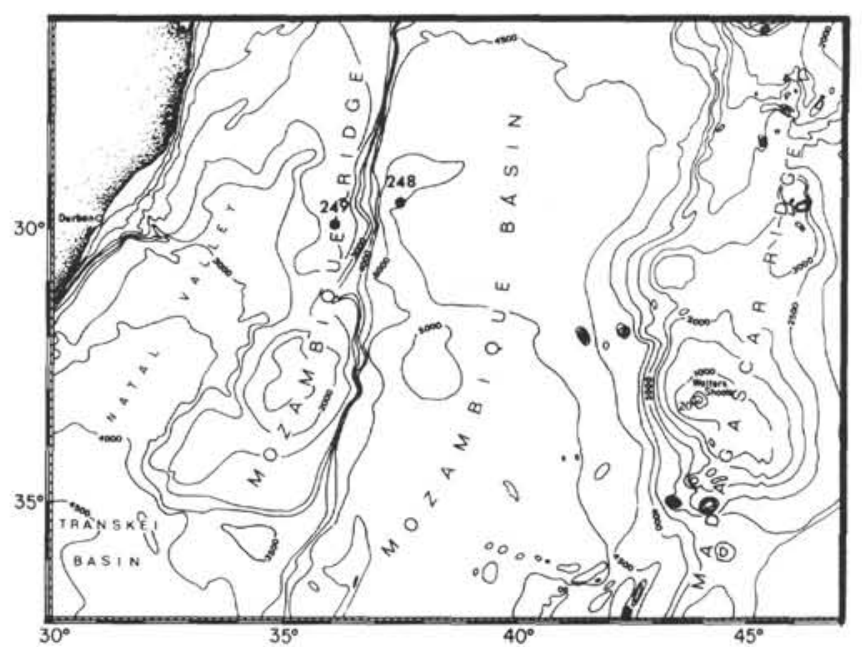

Figure 1. Location map of Sites 248 and 249. 
Interstitial waters were squeezed out of the sediment on the ship as soon as possible after recovery using a pressure of 2400 to $3000 \mathrm{lbs} . / \mathrm{sq}$. in. They were then filtered through millipore membrane filters and sealed in polyethylene tubes for shipment. The sediment that remained was washed to remove soluble salts and dried at $105^{\circ} \mathrm{C}$. Carbonate was then extracted with $0.2 \mathrm{~N} \mathrm{HCOOH}$. By using this method of extracting carbonate, experience has shown that even well-crystallized dolomite will be dissolved providing the material is well pulverized and at least 12 hours are allowed for the reaction. The acid is quite strong and has an effect on the noncarbonate fraction by partly dissolving amorphous or poorly crystallized $\mathrm{Fe} / \mathrm{Mn}$ oxides and removing adsorbed ions (such as $\mathrm{Mg}$ ). However, this effect is only important if small quantities of carbonate are present, such as in the samples from Site 248. Methods used in the analyses are given in Table 1.

In addition to chemical analyses, the noncarbonate material was analyzed by the X-ray diffraction method by H. Rösch (Bundesanstalt für Bodenforschung). He determined quartz, lussatite (unidimensionally disordered low temperature cristobalite), and opaline, quantitatively (Table $2)$. His studies are complemented by the semiquantitative results from the X-ray laboratory at the Deep Sea Drilling Project (Matti et al., this volume).

In order to have a suitable basic value for calculations of trace elements, the noncarbonate has been divided into two parts. The first part contains "free silica" (quartz, lussatite, and opaline material). The second part includes "silicates" and is calculated by subtracting the "free silica" from the noncarbonate (noncarbonate-"free silica"="silicate"). Because the "free silica" contains only very small quantities of trace elements, it can be neglected; therefore, the bulk of the trace elements were calculated by using "silicate" as the basic value, i.e., "silicate" $=100$ percent,

Generally, these calculations give reproducible and accurate results. However, in samples that contain large quantities of "free silica", large deviations can occur. Quartz content can be determined accurately from X-ray

TABLE 1

Methods of Interstitial Water and Sediment Analyses

\begin{tabular}{ll}
\hline \multicolumn{1}{c}{ Ions Sought } & \multicolumn{1}{c}{ Method Used } \\
\hline $\mathrm{Si}$ & $\begin{array}{l}\text { Gravimetrically from the insoluble residue } \\
\text { by the difference before and after treatment } \\
\text { with } \mathrm{H}_{2} \mathrm{~F}_{2} \text {. }\end{array}$ \\
& $\begin{array}{l}\text { Optical spectrophotometry with } \mathrm{H}_{2} \mathrm{O}_{2} . \\
\mathrm{Ti}\end{array}$ \\
$\mathrm{Fe}$ & $\begin{array}{l}\text { Optical spectrophotometry with o-phen- } \\
\text { antroline (less than } 0.5 \text { percent by atomic } \\
\text { absorption). }\end{array}$ \\
$\mathrm{Mn}, \mathrm{Cu}, \mathrm{Zn}, \mathrm{Mg}, \mathrm{Sr}$ & $\begin{array}{l}\text { Atomic absorption. } \\
\mathrm{Ca}\end{array}$ \\
$\begin{array}{l}\text { Automatic titration with EDTA (optical } \\
\text { indication); amounts less than } 0.1 \text { percent } \\
\text { by atomic absorption. }\end{array}$ \\
$\mathrm{Cr}, \mathrm{Ni}, \mathrm{Co}, \mathrm{Mo}, \mathrm{V}, \mathrm{B}$ & $\begin{array}{l}\text { Spectrographically by the method of inner } \\
\text { standard. }\end{array}$ \\
$\mathrm{Na}, \mathrm{K}$ & $\begin{array}{l}\text { Flame photometry. } \\
\text { Conductometrical titration. }\end{array}$ \\
$\mathrm{Cl}, \mathrm{SO} 4$ &
\end{tabular}

TABLE 2

X-ray Analyses of "Free Silica"

\begin{tabular}{lcccc}
\hline Sample & $\begin{array}{c}\text { Depth } \\
(\mathrm{m})\end{array}$ & $\begin{array}{c}\text { Quartz } \\
(\%)\end{array}$ & $\begin{array}{c}\text { Lussatite } \\
(\%)\end{array}$ & $\begin{array}{c}\text { Opaline } \\
(\%)\end{array}$ \\
\hline $248-2-2$ & $3.9-4.0$ & 18 & 5 & $10-15$ \\
$248-4-5$ & $128.4-128.5$ & 17 & 5 & $10-15$ \\
$248-10-1$ & $313.4-313.5$ & 30 & 5 & 10 \\
$248-11-1$ & $361.0-361.1$ & 12 & $30-40$ & 0 \\
$248-12-5$ & $396.4-396.5$ & 8 & 15 & $10-15$ \\
$248-14-3$ & $411.4-411.5$ & 14 & 10 & $15-25$ \\
$249-1-5$ & $7.4-7.5$ & 14 & $10-20$ & $20-30$ \\
$249-2-2$ & $10.9-11.0$ & 18 & 0 & $30-60$ \\
$249-4-5$ & $34.4-34.5$ & 19 & 0 & $24-36$ \\
$249-6-5$ & $53.4-53.5$ & 9 & 12 & 12 \\
$249-8-5$ & $72.4-72.5$ & 15 & $12-24$ & $12-24$ \\
$249-10-5$ & $91.4-91.5$ & 14 & 0 & 14 \\
$249-12-5$ & $110.4-110.5$ & 15 & 0 & $13-26$ \\
$249-14-5$ & $138.4-138.5$ & 14 & 0 & $18-27$ \\
$249-15-5$ & $157.4-157.5$ & 8 & $8-16$ & $8-16$ \\
$249-16-1$ & $170.4-170.5$ & 13 & 8 & $8-16$ \\
$249-17-5$ & $185.4-185.5$ & 16 & 0 & $10-15$ \\
$249-19-3$ & $222.4-222.5$ & 12 & 5 & $5-10$ \\
$249-21-5$ & $263.4-263.5$ & 9 & $5-10$ & $5-10$ \\
$249-23-3$ & $288.4-288.5$ & 21 & $30-50$ & 0 \\
\hline
\end{tabular}

diffraction studies, but lussatite and opaline determinations are not as exact. Therefore, the noncarbonate "free silica" calculation can show a large deviation which will be greater when the "free silica" amount is large. Examples are in Samples 249-2-2, 140-150 cm and 249-8-5, 140-150 cm, which have the highest amount of "free silica"; the trace elements of those samples, if calculated with "silicate" as the basic value, show very high values. These values should be disregarded.

\section{GENERAL GEOLOGIC SETTING}

\section{Site 248}

Figure 2 presents a summary of sediment descriptions, cored intervals, ages, and sample locations. Unit I has mostly terrigenous sediments, including sand, silt, and clay, which were eroded from East Africa and Madagascar. Unit II is a greenish-gray laminated unit that consists mostly of hemipelagic deposits of devitrified volcanic clay and silty clay. Rare white and pale pink laminae consist of calcite and rhodochrosite, and brownish-gray clay-rich beds mark devitrified volcanic ash. Pyrite is common and occurs as distinct segregations and as thin laminae (concentrations along bedding planes). The presence of lussatite and clinoptilolite and the dominance of palygorskite over montmorillonite in the clay fractions $(<2 \mu$, DSDP X-ray results) are significant mineralogic characteristics. Both plagioclase and potash feldspars are common. Radiolarian tests are concentrated in lenses and in thin silt-rich beds, along with quartz, feldspar, and chlorite.

Unit III consists of brown clay and brown silt-bearing clay. Near the top of the unit, in Core 14, Section 1, moderate brown, dark reddish-brown, and blackish-red thin beds give the sediments a banded appearance. These brown and red colors are in strong contrast with the overlying greenish-gray unit. There is a nearly ubiquitous terrigenous fraction within the sediments which includes kaolinite, illite, chlorite, potash feldspar, and quartz. 


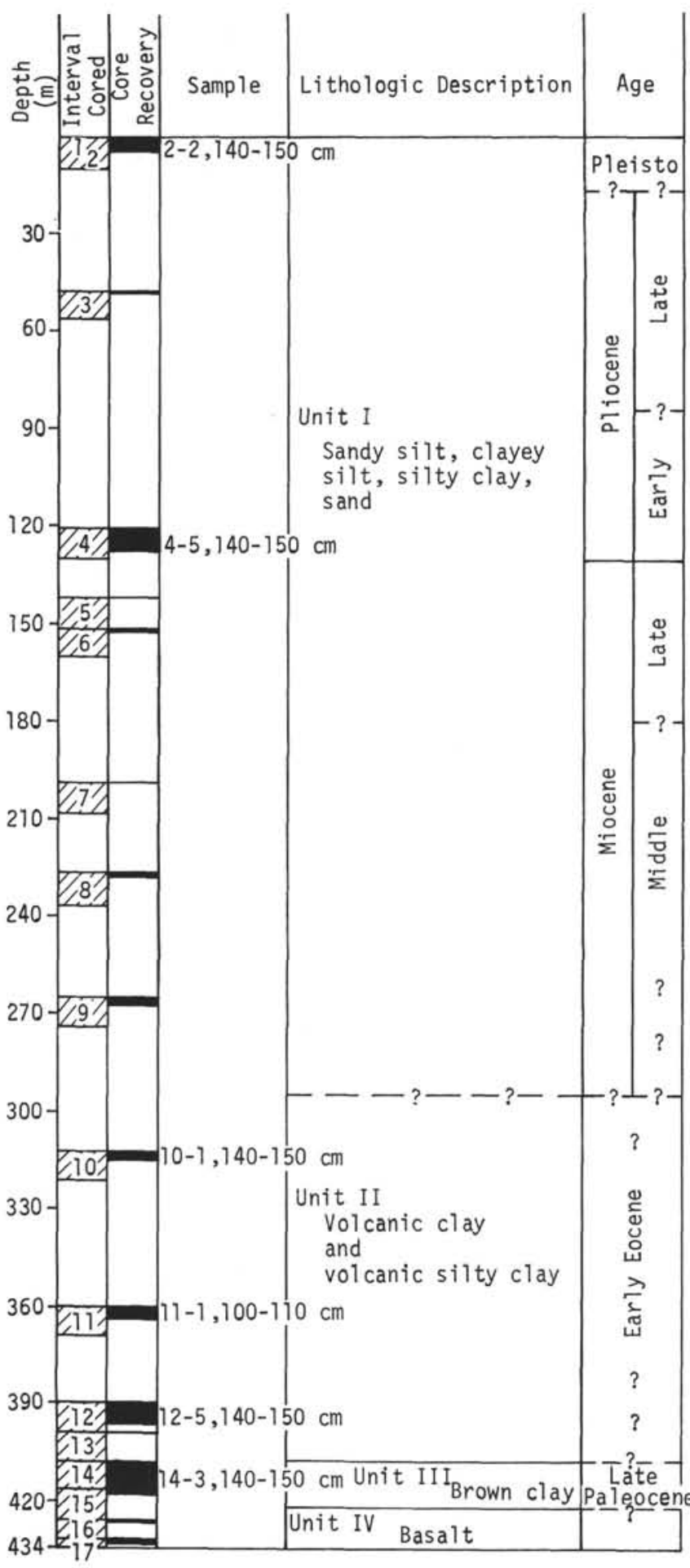

Figure 2. Cored intervals, core recovery, sample locations, lithologic descriptions, and ages, Site 248.

Unit II was deposited in a reducing environment, whereas Unit III accumulated in an oxidizing one. The top of Unit III has interbeds of brown and greenish gray colors, which suggests that the redox conditions changed rather slowly and that these changes were nearly cyclical.

Sedimentation rates are somewhat uncertain at this site because of the rarity of fossils suitable for paleontological data. The lower two units have low sedimentation rates, possibly as low as $2.7 \mathrm{~m} / \mathrm{m}$.y. and only as high as 5.2 $\mathrm{m} / \mathrm{m} . \mathrm{y}$. The sedimentation rate for Unit I reflects an increased terrigenous input and is calculated to be approximately $8 \mathrm{~m} / \mathrm{m} . \mathrm{y}$. in the late middle Miocene,"16 $\mathrm{m} / \mathrm{m} . \mathrm{y}$. in the late Miocene, and it could be as great as 50 $\mathrm{m} / \mathrm{m} . \mathrm{y}$. in the late Pliocene.

Only six samples were selected from this lithologically diverse site (Table 3); however, they are quite representative of the lithologic units.

TABLE 3

Sediment Descriptions and X-ray Results (Rösch), Site 248

\begin{tabular}{|c|c|c|}
\hline Sample & Sediment Description & $\begin{array}{l}\text { X-ray Results } \\
\text { (Qualitative) }\end{array}$ \\
\hline $2-2,140-150 \mathrm{~cm}$ & $\begin{array}{l}\text { Alternating clay-rich } \\
\text { nanno ooze and } \\
\text { sandy silt. }\end{array}$ & $\begin{array}{l}\text { Quartz, feldspar, opa- } \\
\text { line, kaolinite, illite, } \\
\text { lussatite, calcite, mont- } \\
\text { morillonite, a mixed- } \\
\text { layer mineral. }\end{array}$ \\
\hline $4-5,140-150 \mathrm{~cm}$ & $\begin{array}{l}\text { Silty clay with rare } \\
\text { streaks of nanno } \\
\text { ooze. }\end{array}$ & $\begin{array}{l}\text { Quartz, feldspar, opa- } \\
\text { line, illite, kaolinite, } \\
\text { lussatite. }\end{array}$ \\
\hline $10-1,140-150 \mathrm{~cm}$ & $\begin{array}{l}\text { Laminated silty clay } \\
\text { and volcanic clay. }\end{array}$ & $\begin{array}{l}\text { Quartz, feldspar, opa- } \\
\text { line, illite, kaolinite, } \\
\text { calcite, lussatite, } \\
\text { dolomite. }\end{array}$ \\
\hline $11-1,100-110 \mathrm{~cm}$ & $\begin{array}{l}\text { Laminated silty clay } \\
\text { and volcanic clay. }\end{array}$ & $\begin{array}{l}\text { Lussatite, quartz, paly- } \\
\text { gorskite, feldspar, mont- } \\
\text { morillonite, illite. }\end{array}$ \\
\hline $12-5,140-150 \mathrm{~cm}$ & $\begin{array}{l}\text { Volcanic silty clay; } \\
\text { sample is greatly } \\
\text { deformed; a } \\
\text { "drilling breccia." }\end{array}$ & $\begin{array}{l}\text { Quartz, feldspar, lussa- } \\
\text { tite, palygorskite, mont- } \\
\text { morillonite, opaline, } \\
\text { illite, calcite. }\end{array}$ \\
\hline $14-3,140-150 \mathrm{~cm}$ & $\begin{array}{l}\text { Brown clay (silt- } \\
\text { rich), banded in } \\
\text { brown, brownish } \\
\text { red, and blackish } \\
\text { red. }\end{array}$ & $\begin{array}{l}\text { Quartz, opaline, lussa- } \\
\text { tite, feldspar, calcite, } \\
\text { palygorskite, } \\
\text { chlorite. }\end{array}$ \\
\hline
\end{tabular}

Site 249

A summary diagram of cored intervals, ages, sample locations, and sediment descriptions is given in Figure 3. Unit I is predominantly a foram-rich nanno ooze which ranges from middle Miocene to Quaternary in age. Within the unit, foraminifera percentages range from about 5 to 55 percent. Clay minerals are rare above 32 meters, but below that depth, they comprise up to 10 percent of the sediment in some beds. The sediment is disturbed, because of the drilling process, above 115 meters.

Unit II is predominantly a foram-bearing clay-rich nanno chalk. It contains less foraminifera, relative to nannofossils, and more clay than Unit I, and it is more lithified, i.e., a chalk rather than an ooze. Major noncarbonate components in this unit are quartz, potash feldspar, mica-illite, and palygorskite, with some lussatite, montmorillonite, and kaolinite. Bioturbation is very common throughout the cored sequence. This unit is Late Cretaceous (CampanianMaestrichtian) in age and is separated from both the overlying and the underlying units by major hiatuses.

Unit III is mostly a gray and olive-black silty claystone and volcanic siltstone. The boundary between Units II and III was selected at a depth of 287 meters in Section 2, Core 23 , where there is a significant increase in clay and an 


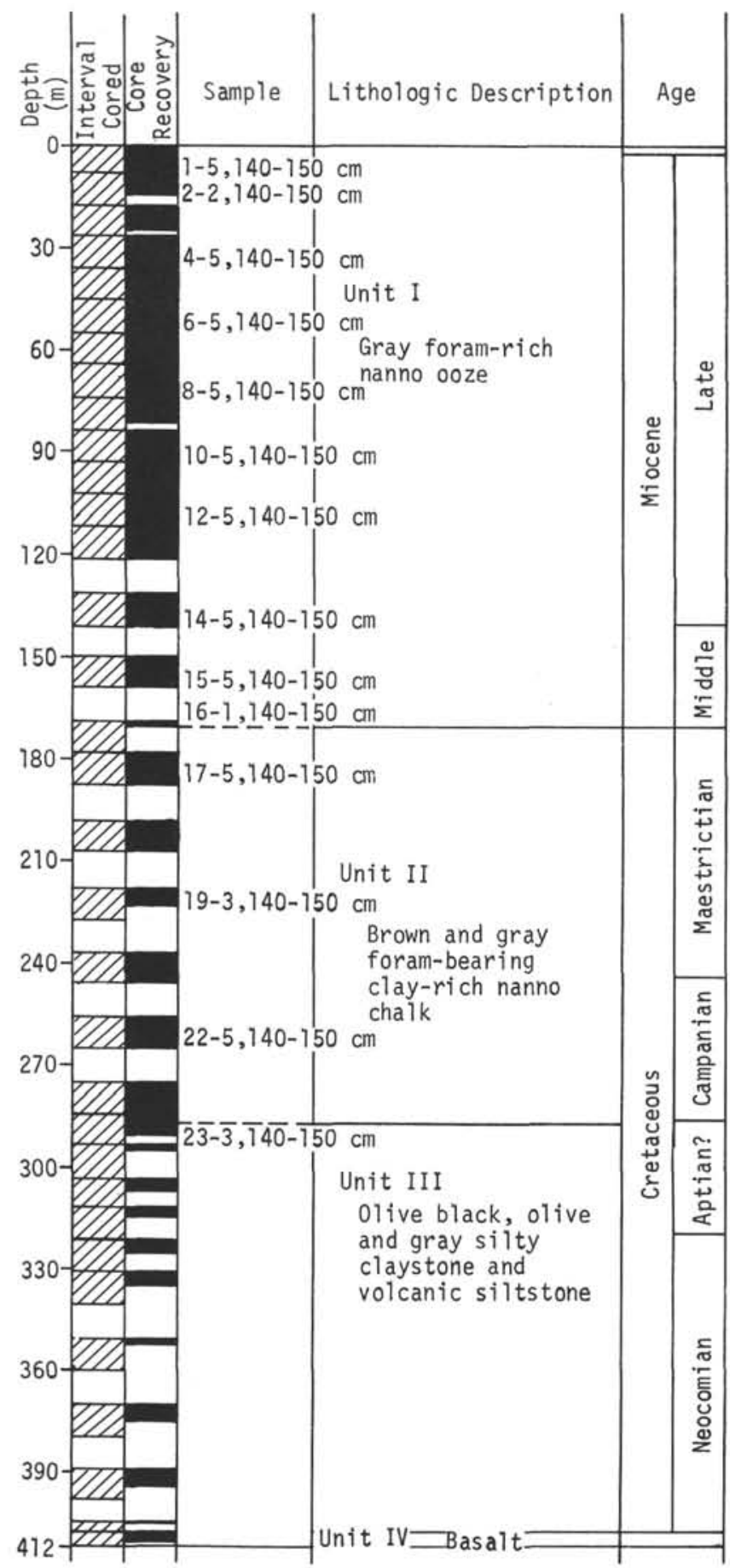

Figure 3. Cored intervals, core recovery, sample locations, lithologic descriptions, and ages, Site 249.

accompanying decrease in biogenous components. The boundary is not sharp. The dominant lithologies of Unit III actually first appear at 290 meters where the color changes to gray and olive black and the sediments become rich in volcanic detritus, pyrite, and carbon. The last sample for this geochemical study was taken at 288.5 meters in a silt-rich claystone, above the color change. The entire unit is of Early Cretaceous age.

Sedimentation rates in Unit I have a wide range. For instance, during the middle Miocene and most of the late
Miocene, the rate was about $8 \mathrm{~m} / \mathrm{m} . \mathrm{y}$., whereas in the latest late Miocene, a rate of $60 \mathrm{~m} / \mathrm{m} . y$. was calculated. In Unit II, sedimentation rates for the Maestrichtian are about 17 $\mathrm{m} / \mathrm{m} . \mathrm{y}$.

Fourteen samples were selected from this site, most of which are from the nanno ooze (Unit I) and nanno chalk (Unit II) sequences. One sample was selected from the silty claystone (Unit III) sequence. Sediment descriptions and qualitative X-ray result are given in Table 4.

TABLE 4

Sediment Descriptions and X-ray Results (Rösch), Site 249

\begin{tabular}{|c|c|c|}
\hline Sample & Sediment Description & $\begin{array}{l}\text { X-ray Results } \\
\text { (Qualitative) }\end{array}$ \\
\hline $1-5,140-150 \mathrm{~cm}$ & $\begin{array}{l}\text { Foram-rich nanno } \\
\text { ooze }\end{array}$ & $\begin{array}{l}\text { Calcite, quartz, opaline, } \\
\text { lussatite, feldspar. }\end{array}$ \\
\hline $2-2,140-150 \mathrm{~cm}$ & $\begin{array}{l}\text { Foram-rich nanno } \\
\text { ooze }\end{array}$ & Calcite, opaline, quartz. \\
\hline $4-5,140-150 \mathrm{~cm}$ & $\begin{array}{l}\text { Foram-rich nanno } \\
\text { ooze }\end{array}$ & $\begin{array}{l}\text { Calcite, opaline, quartz, } \\
\text { kaolinite, } \\
\text { montmorillonite. }\end{array}$ \\
\hline $6-5,140-150 \mathrm{~cm}$ & $\begin{array}{l}\text { Foram-rich nanno } \\
\text { ooze }\end{array}$ & $\begin{array}{l}\text { Calcite, opaline, quartz, } \\
\text { kaolinite, feldspar, } \\
\text { lussatite. }\end{array}$ \\
\hline $8-5,140-150 \mathrm{~cm}$ & $\begin{array}{l}\text { Foram-rich nanno } \\
\text { ooze }\end{array}$ & $\begin{array}{l}\text { Calcite, opaline, quartz, } \\
\text { kaolinite, feldspar, } \\
\text { montmorillonite, } \\
\text { lussatite. }\end{array}$ \\
\hline $10-5,140-150 \mathrm{~cm}$ & $\begin{array}{l}\text { Foram-rich nanno } \\
\text { ooze }\end{array}$ & $\begin{array}{l}\text { Calcite, opaline, quartz, } \\
\text { kaolinite, montmoril- } \\
\text { lonite, feldspar. }\end{array}$ \\
\hline $12-5,140-150 \mathrm{~cm}$ & $\begin{array}{l}\text { Foram-rich nanno } \\
\text { ooze }\end{array}$ & $\begin{array}{l}\text { Calcite, opaline, quartz, } \\
\text { feldspar. }\end{array}$ \\
\hline $14-5,140-150 \mathrm{~cm}$ & $\begin{array}{l}\text { Foram-rich nanno } \\
\text { ooze }\end{array}$ & $\begin{array}{l}\text { Calcite, opaline, quartz, } \\
\text { illite, kaolinite, mont- } \\
\text { morillonite, feldspar. }\end{array}$ \\
\hline $15-5,140-150 \mathrm{~cm}$ & $\begin{array}{l}\text { Foram/clay-bearing } \\
\text { nanno ooze }\end{array}$ & $\begin{array}{l}\text { Calcite, opaline, quartz, } \\
\text { lussatite, kaolinite, } \\
\text { illite, feldspar. }\end{array}$ \\
\hline $16-1,140-150 \mathrm{~cm}$ & $\begin{array}{l}\text { Foram-rich nanno } \\
\text { chalk }\end{array}$ & $\begin{array}{l}\text { Calcite, opaline, quartz, } \\
\text { feldspar, kaolinite, } \\
\text { illite, lussatite. }\end{array}$ \\
\hline $17-5,140-150 \mathrm{~cm}$ & $\begin{array}{l}\text { Foram-bearing } \\
\text { clayey nanno chalk }\end{array}$ & $\begin{array}{l}\text { Quartz, opaline, feld- } \\
\text { spar, illite, kaolinite, } \\
\text { calcite, montmorillonite. }\end{array}$ \\
\hline $19-3,140-150 \mathrm{~cm}$ & $\begin{array}{l}\text { Clay-rich nanno } \\
\text { chalk }\end{array}$ & $\begin{array}{l}\text { Opaline, quartz, illite, } \\
\text { feldspar, calcite, mont- } \\
\text { morillonite, lussatite. }\end{array}$ \\
\hline $21-5,140-150 \mathrm{~cm}$ & $\begin{array}{l}\text { Foram-bearing clay- } \\
\text { rich nanno chalk }\end{array}$ & $\begin{array}{l}\text { Quartz, opaline, mont- } \\
\text { morillonite, illite, feld- } \\
\text { spar, lussatite. }\end{array}$ \\
\hline $23-3,140-150 \mathrm{~cm}$ & $\begin{array}{l}\text { Nanno-bearing silt- } \\
\text { rich claystone }\end{array}$ & $\begin{array}{l}\text { Lussatite, quartz, feld- } \\
\text { spar, montmorillonite, } \\
\text { calcite, mixed layer } \\
\text { clay. }\end{array}$ \\
\hline
\end{tabular}

\section{GEOCHEMICAL RESULTS AND DISCUSSION}

Site 248

\section{Noncarbonate}

Site 248 sediments mostly were deposited below the CCD and have a high content of terrigenous materials. 
Therefore, they have a high noncarbonate fraction; for example, Sample 248-2-2 (3.9-4.0 m depth) contains about 92 percent noncarbonate, and the rest of the samples have as much as 99 percent. Quartz content ranges between 8 and 30 percent in the noncarbonate, and maxima and minima both occur in Unit II. Results of the noncarbonate chemical studies are presented in Figure 4 and Table 5.

In Unit I (2 samples), the chemistries are fairly homogenous. There are small enrichments in $\mathrm{Cr}, \mathrm{V}$, and $\mathrm{Ti}$, which may result from the terrigenous influence. The enrichment in $\mathrm{Ca}$ also might be related to the dominantly terrigenous sediments in that unit; probably, it is the result of higher plagioclase feldspar content.

Unit II (3 samples) seems heterogenous at first inspection. However, on closer inspection, the two lower samples are very similar. During studies on the sediments, it was noted that the upper part of the unit (near the top of Core 10) contains a high amount of terrigenous sediment, very similar to that in Unit I. The two lower samples were selected from the palygorskite- (X-ray results, Matti et al., this volume) and lussatite-rich volcanic clay, and they can be considered as being diagnostic of Unit II. Relative to the younger samples, these two samples show decreases in $\mathrm{Cr}$, $\mathrm{Co}, \mathrm{Ca}, \mathrm{Mn}, \mathrm{Fe}, \mathrm{B}$, and $\mathrm{Ni}$ and an increase in $\mathrm{Mg}$. The unit is volcanogenic in large part and most of these decreases probably are associated with the dilution by volcanic materials. An increase in Mg most likely is associated with the large amount of palygorskite, which contains $\mathrm{Mg}$ as a major cation.

Only one sample was selected from Unit III, the thin-bedded brown clay and reddish-brown clay. This unit appears to be similar to some basal $\mathrm{Fe} / \mathrm{Mn}$ deposits that have been recovered from the East Pacific Rise area, both in physical characteristics and in some chemistry. There certainly are high contents of $\mathrm{Mn}, \mathrm{Fe}, \mathrm{Ti}$, and $\mathrm{V}$, but there is no increase in $\mathrm{Cu}, \mathrm{Co}, \mathrm{Mo}$, and $\mathrm{Ni}$ as was expected; instead, there actually are decreases in Co and Mo. These elements apparently are affected by postdepositional mobility, which is related to redox reactions similar to those described by Bonatti et al. (1971) who note (p. 195) that $\mathrm{Mn}$ appears to migrate much more efficiently than even $\mathrm{Ni}$ and $\mathrm{Co}$. Because $\mathrm{Ni}$ and $\mathrm{Co}$ do not form minerals of their own in pelagic sediments, they generally are hosted in $\mathrm{Mn}$ and $\mathrm{Fe}$ minerals. An example of what might happen as the elements cross the Eh interface and enter a reducing zone, is that a quantity of $\mathrm{Ni}$ and $\mathrm{Co}$ may be prevented from following $\mathrm{Mn}$ in its migration in the pore solution, by being captured in iron hydroxides and sulfides. It seems likely, therefore, that this facies may indeed be a basal $\mathrm{Fe} / \mathrm{Mn}$ deposit which formed near a spreading ridge and that the present distribution of elements is related to original changes in redox conditions which had affected element mobilities. Because of the banded nature of the sediment, which is very noticeable in the upper part of the unit where both brown and grayish-green interbeds occur, this unit may warrant further study, particularly with regard to the mobilization of elements across Eh interfaces in an old, deeply buried, $\mathrm{Fe} / \mathrm{Mn}$ sequence.

\section{Carbonate}

The carbonate results for Site 248 are shown in parentheses in Table 6 . The results are much too high because the percentage of carbonate relative to noncarbonate is small and many of the ions were removed from the clays during carbonate extraction. Also, some of the oxides no doubt are soluble in the $0.2 \mathrm{~N} \mathrm{HCOOH}$. Therefore, these values should be ignored.

\section{Interstitial Water}

Analyses of the interstitial waters (Table 7, Figure 5) show that with depth there are decreases in contents of $\mathrm{Na}$, $\mathrm{K}$, and $\mathrm{Mg}$ and increases in $\mathrm{Ca}$ and $\mathrm{Sr}$ (to about $300 \mathrm{~m}$, below which it is constant). $\mathrm{C} 1$ shows no regularity, and $\mathrm{SO}_{4}$ also is somewhat irregular, although there is a notable decrease between the first sample at 4 meters and 128 meters. The depletion is related to reduction of sulfate to sulfide with depth. Gieskes (this volume) discusses this relationship in detail. Any explanations for the changes in interstitial water chemistries must be considered speculative at this time. Changes in $\mathrm{Ca}, \mathrm{Mg}$, and $\mathrm{Sr}$ might be related to the diagenesis of carbonate even though there are few carbonates in the hole. The decrease in $\mathrm{Mg}$ might be caused by the formation of dolomite although another reason for the decrease might be that $\mathrm{Mg}$ is depleted from the interstitial water because of the formation of palygorskite, which is a Mg-rich clay mineral. The increase in $\mathrm{Sr}$ is small and, possibly, might be related to the loss of $\mathrm{Sr}$ during the aragonite-calcite conversion. However, no aragonite was identified in the samples. Another possibility is that small amounts of Si might be lost during calcite (organisms)calcite recrystallization.

In Unit II, the interstitial water shows significant changes in the amounts of $\mathrm{Na}, \mathrm{K}, \mathrm{Mg}, \mathrm{C} 1$, and $\mathrm{SO}_{4}$. The lower $\mathrm{Na}, \mathrm{K}$, and $\mathrm{Mg}$ might be related to the devitrification of volcanic ash which yielded montmorillonite and palygorskite. $\mathrm{Na}$ and $\mathrm{K}$ can be absorbed between layers in montmorillonite, and $\mathrm{Mg}$ replaces $\mathrm{Al}$ in both montmorillonite and palygorskite. Another possibility is that these cations are taken up by the zeolite, clinoptilolite. The $\mathrm{SO}_{4}$ content, after the depletion in Unit I, increases in Unit II which may be related to changes in sedimentation rate as described by Gieskes (this volume).

\section{Site 249}

\section{Noncarbonate}

The noncarbonate percentages at Site 249 are notably different from those at Site 248 except for the bottom samples, which have a low carbonate content. In Unit I, the noncarbonate ranges from 9 to 17 percent, in Unit II, from 48 to 51 percent, and in Unit III (one sample), it is 99 percent. Chemistries of noncarbonate sediments are given in Table 5 and Figure 6.

Unit $\mathrm{I}$ is enriched in $\mathrm{Cu}, \mathrm{Co}, \mathrm{Mo}, \mathrm{Zn}, \mathrm{Ni}, \mathrm{B}, \mathrm{Ca}, \mathrm{V}$, and Ti. The creation of sulfides might be responsible for the high values of $\mathrm{Cu}, \mathrm{Co}, \mathrm{Mo}, \mathrm{Zn}$, and $\mathrm{Ni}$ (Pyrite is a common constituent). An indication that this may have occurred can be inferred from observing the low Mn content in carbonates of this unit. The Mn that is dissolved with the carbonates in $0.2 \mathrm{~N} \mathrm{HCOOH}$ is not derived from the carbonate crystal lattices. Rather, it is part of the amorphous or poorly crystallized, chemically formed Mn oxides which occur only in an oxidizing environment (Marchig, in press). Boron enrichment probably was caused by the fixing of this 

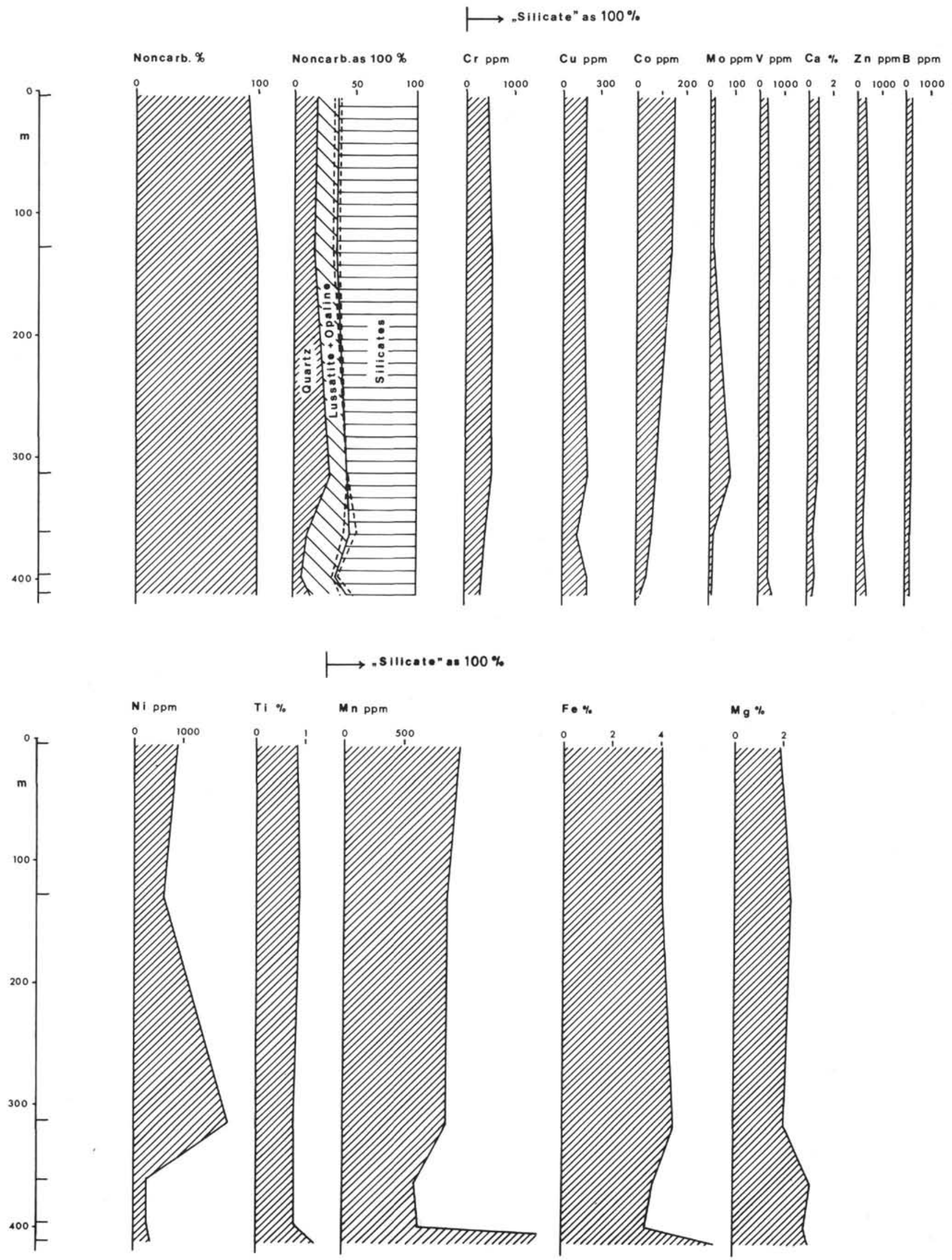

Figure 4. Noncarbonate chemistry, Site 248. 
TABLE 5

Noncarbonate Analyses, Sites 248 and 249

\begin{tabular}{|c|c|c|c|c|c|c|c|c|c|c|c|c|c|c|c|}
\hline Sample & $\begin{array}{l}\text { Depth } \\
\text { (m) }\end{array}$ & $\begin{array}{c}\text { "Silicate" } \\
(\%)\end{array}$ & $\begin{array}{c}\mathrm{Ti} \\
(\%)\end{array}$ & $\begin{array}{c}\mathrm{Cr} \\
(\mathrm{ppm})\end{array}$ & $\begin{array}{c}\mathrm{Cu} \\
(\mathrm{ppm})\end{array}$ & $\begin{array}{c}\mathrm{Co} \\
(\mathrm{ppm})\end{array}$ & $\begin{array}{l}\text { Mo } \\
(\mathrm{ppm})\end{array}$ & $\underset{(p p m)}{V}$ & $\begin{array}{l}\mathrm{Ca} \\
(\%)\end{array}$ & $\begin{array}{c}\mathrm{Zn} \\
(\mathrm{ppm})\end{array}$ & $\begin{array}{c}\mathrm{Mn} \\
(\mathrm{ppm})\end{array}$ & $\begin{array}{l}\mathrm{Mg} \\
(\%)\end{array}$ & $\begin{array}{l}\mathrm{Fe} \\
(\%)\end{array}$ & $\underset{(\mathrm{ppm})}{\mathrm{B}}$ & $\begin{array}{c}\mathrm{Ni} \\
(\mathrm{ppm})\end{array}$ \\
\hline $248-2-2$ & $3.9-4.0$ & 59 & 0.85 & 430 & 190 & 150 & 15 & 310 & 0.85 & 320 & 950 & 1.85 & 4.03 & 220 & 890 \\
\hline $248-4-5$ & $128.4-128.5$ & 64 & 0.89 & 520 & 170 & 150 & 14 & 410 & 0.91 & 510 & 860 & 2.30 & 4.08 & 210 & 610 \\
\hline $248-10-1$ & $313.4-313.5$ & 55 & 0.77 & 550 & 200 & 80 & 80 & 410 & 0.82 & 350 & 850 & 2.07 & 4.55 & 220 & 1930 \\
\hline $248-11-1$ & $361.0-361.1$ & 53 & 0.77 & 390 & 120 & 60 & 17 & 400 & 0.43 & 280 & 590 & 3.15 & 3.68 & 190 & 280 \\
\hline $248-12-5$ & $396.4-396.5$ & 64 & 0.76 & 330 & 200 & 40 & 10 & 350 & 0.56 & 350 & 630 & 2.90 & 3.42 & 190 & 280 \\
\hline $248-14-3$ & $411.4-411.5$ & 56 & 1.19 & 320 & 200 & 10 & 10 & 570 & 0.41 & 400 & 5800 & 3.09 & 6.18 & 210 & 350 \\
\hline $249-1-5$ & $7.4-7.5$ & 7 & 0.64 & 1390 & 440 & 310 & 190 & 900 & 16.14 & 1970 & 440 & 2.29 & 4.00 & 2160 & 1070 \\
\hline $249-2-2$ & $10.9-11.0$ & 3 & 1.30 & 3070 & 1030 & 930 & 400 & 2170 & 5.33 & 3330 & 1030 & 4.33 & 7.33 & 7000 & 1970 \\
\hline $249-4-5$ & $34.3-34.5$ & 6 & 0.80 & 1350 & 520 & 270 & 270 & 3280 & 12.50 & 570 & 520 & 2.33 & 4.83 & 3580 & 1420 \\
\hline $249-6-5$ & $53.4-53.5$ & 8 & 0.68 & 880 & 390 & 350 & 310 & 910 & 2.38 & 1490 & 390 & 2.00 & 3.88 & 2690 & 1020 \\
\hline $249-8-5$ & $72.4-72.5$ & 6 & 1.07 & 1820 & 520 & 370 & 200 & 1250 & 6.00 & 570 & 520 & 2.67 & 4.67 & 3500 & 1400 \\
\hline $249-10-5$ & $91.4-91.5$ & 8 & 0.50 & 1550 & 390 & 280 & 240 & 780 & 1.38 & 1180 & 390 & 1.63 & 3.88 & 2640 & 740 \\
\hline $249-12-5$ & $110.4-110.5$ & 7 & 0.82 & 1260 & 440 & 360 & 190 & 990 & 1.57 & 1110 & 440 & 2.00 & 4.14 & 3440 & 1030 \\
\hline $249-14-5$ & $138.4-138.5$ & 10 & 0.80 & 1280 & 310 & 380 & 160 & 510 & 1.60 & 1090 & 630 & 2.00 & 4.20 & 2530 & 770 \\
\hline $249-15-5$ & $157.4-157.5$ & 11 & 0.49 & 1350 & 280 & 410 & 120 & 4.10 & 2.09 & 1080 & 570 & 2.00 & 4.45 & 2100 & 660 \\
\hline $249-16-1$ & $170.4-170.5$ & 11 & 0.67 & 1140 & 430 & 60 & 120 & 960 & 5.27 & 1270 & 570 & 2.00 & 4.36 & 2510 & 530 \\
\hline $249-17-5$ & $185.4-185.5$ & 36 & 0.61 & 400 & 130 & 140 & 50 & 290 & 0.86 & 290 & 690 & 2.61 & 4.00 & 590 & 340 \\
\hline $249-19 \cdot 3$ & $222.4-222.5$ & 37 & 0.61 & 550 & 130 & 80 & 19 & 610 & 0.97 & 500 & 510 & 2.41 & 4.16 & 590 & 720 \\
\hline $249-21-5$ & $263.4-263.5$ & 39 & 0.70 & 460 & 160 & 50 & 30 & 440 & 0.79 & 360 & 520 & 2.41 & 4.05 & 470 & 630 \\
\hline $249-23-3$ & $288.4-288.5$ & 39 & 0.60 & 270 & 200 & 20 & 20 & 590 & 0.92 & 230 & 240 & 1.79 & 2.74 & 230 & 360 \\
\hline
\end{tabular}

Note: "Silicate" is the rest of noncarbonate if free $\mathrm{SiO}_{2}$ is subtracted: $100-$ sum of carbonates = noncarbonate; noncarbonate $-($ quartz + lussatite + opaline material)

Bulk of above trace elements were calculated using "silicate" as the basic value, i.e., "silicate" $=100$ percent.

TABLE 6

Carbonate Analyses, Sites 248 and 249

\begin{tabular}{|c|c|c|c|c|c|c|}
\hline Sample & $\begin{array}{l}\text { Depth } \\
\text { (m) }\end{array}$ & $\begin{array}{c}\text { Sum of Carbonates } \\
\left(\mathrm{CaCO}_{3}+\underset{(\%)}{\left.\mathrm{SrCO}_{3}+\mathrm{MgCO}_{3}\right)}\right.\end{array}$ & $\begin{array}{c}\mathrm{SrCO}_{3} \\
(\%)\end{array}$ & $\begin{array}{c}\mathrm{MgCO}_{3} \\
(\%)\end{array}$ & $\underset{(\mathrm{ppm})}{\mathrm{Fe}}$ & $\begin{array}{c}\mathrm{Mn} \\
(\mathrm{ppm})\end{array}$ \\
\hline $248-2-2$ & $3.9-4.0$ & 8.4 & $(0.34)$ & $(1.22)$ & $(2600)$ & $(11700)$ \\
\hline $248-4-5$ & $128.4-128.5$ & 1.4 & $(0.51)$ & $(4.39)$ & $(42100)$ & $(96000)$ \\
\hline $248-10-1$ & $313.4-313.5$ & 0.8 & $(0.63)$ & $(6.84)$ & $(26100)$ & $(21400)$ \\
\hline $248-11-1$ & $361.0-361.1$ & 0.7 & $(0.70)$ & $(8.01)$ & $(32000)$ & ( 7900) \\
\hline $248-12-5$ & $396.4-396.5$ & 0.8 & $(0.63)$ & $(6.84)$ & $(13100)$ & $(6000)$ \\
\hline $248-14-3$ & $411.4-411.5$ & 0.9 & $(0.79)$ & (5.53) & ( 340$)$ & $(34900)$ \\
\hline $249-1-5$ & $7.4-7.5$ & 86.1 & 0.26 & 0.038 & 230 & 200 \\
\hline $249-2-2$ & $10.9-11.0$ & 91.1 & 0.25 & 0.036 & 620 & 210 \\
\hline $249-4-5$ & $34.3-34.5$ & 88.6 & 0.26 & 0.041 & 600 & 230 \\
\hline $249-6-5$ & $53.4-53.5$ & 88.0 & 0.25 & 0.043 & 650 & 210 \\
\hline $249-8-5$ & $72.4-72.5$ & 88.3 & 0.23 & 0.046 & 640 & 200 \\
\hline $249-10-5$ & $91.4-91.5$ & 89.2 & 0.23 & 0.043 & 640 & 250 \\
\hline $249-12-5$ & $110.4-110.5$ & 88.9 & 0.22 & 0.061 & 840 & 220 \\
\hline $249-14-5$ & $138.4-138.5$ & 84.5 & 0.22 & 0.051 & 670 & 330 \\
\hline $249-15-5$ & $157.4-157.5$ & 83.6 & 0.29 & 0.045 & 460 & 430 \\
\hline $249-16-1$ & $170.4-170.5$ & 83.6 & 0.27 & 0.043 & 140 & 350 \\
\hline $249-17-5$ & $185.4-185.5$ & 49.8 & 0.19 & 0.14 & 0 & 1070 \\
\hline $249-19-3$ & $222.4-222.5$ & 51.4 & 0.19 & 0.24 & 240 & 1730 \\
\hline $249-21-5$ & $263.4-263.5$ & 49.1 & 0.17 & 0.10 & 240 & 1690 \\
\hline $249-23-3$ & $288.4-288.5$ & 0.9 & $(0.33)$ & $(7.03)$ & $(16700)$ & ( 2790) \\
\hline
\end{tabular}

Note: Numbers in parentheses show values that are too high (see discussion).

${ }^{\mathrm{a}}$ In $\mathrm{O} . \phi 2 \mathrm{~N} \mathrm{HCOOH}$ extract.

element in clay minerals (Harder, 1961); therefore, B enrichment should be dependent on clay quantity (and probably type). Part of the $\mathrm{Ca}$ enrichment might be related to an increase in plagioclase, although it is more likely that the greater part is the result of incomplete dissolution during treatment with $\mathrm{HCOOH}$ because of the large quantity of carbonate in the sample.

Unit II, when compared with Unit I, is depleted in all elements studied except $\mathrm{Mg}$. Iron content changes very little and the magnesium probably is tied up in the palygorskite. In this unit, the $\mathrm{Mn}$ in the carbonate fraction is enriched; consequently, the environment was oxidative. No authigenic sulfides are present. Although some heavy minerals were noted in shipboard smear slide studies, they apparently are not in sufficient quantities to greatly affect the noncarbonate sediment chemistry.

Unit III is depleted, relative to Unit $\mathrm{I}$, in the elements $\mathrm{Ni}, \mathrm{Ti}, \mathrm{Mn}, \mathrm{Fe}, \mathrm{Mg}$, and possibly $\mathrm{Cr}, \mathrm{Co}, \mathrm{Zn}$, and $\mathrm{B}$. This sample was taken from the top of a volcanic-rich sediment which had undergone changes during diagenesis and formed several authigenic minerals such as clinoptilolite, montmorillonite, and palygorskite which would have an effect on 
TABLE 7

Interstitial Water Analyses, Sites 248 and 249

\begin{tabular}{lcccccccc}
\hline Sample & $\begin{array}{c}\text { Depth } \\
(\mathrm{m})\end{array}$ & $\begin{array}{c}\mathrm{Na} \\
(\mathrm{mg} / \mathrm{l})\end{array}$ & $\begin{array}{c}\mathrm{K} \\
(\mathrm{mg} / \mathrm{l})\end{array}$ & $\begin{array}{c}\mathrm{Mg} \\
(\mathrm{mg} / \mathrm{l})\end{array}$ & $\begin{array}{c}\mathrm{Ca} \\
(\mathrm{mg} / \mathrm{l})\end{array}$ & $\begin{array}{c}\mathrm{Sr} \\
(\mathrm{mg} / \mathrm{l})\end{array}$ & $\begin{array}{c}\mathrm{Cl} \\
(\mathrm{mg} / \mathrm{l})\end{array}$ & $\begin{array}{c}\mathrm{SO}_{4} \\
(\mathrm{mg} / \mathrm{l})\end{array}$ \\
\hline $248-2-2$ & $3.9-4.0$ & 10,700 & 445 & 1295 & 500 & 15 & 20,930 & 2610 \\
$248-4-5$ & $128.4-128.5$ & 10,500 & 310 & 1210 & 500 & 15 & 20,290 & 1830 \\
$248-10-1$ & $313.4-313.5$ & 10,200 & 205 & 1070 & 1000 & 20 & 19,640 & 2170 \\
$248-11-1$ & $361.0-361.1$ & 10,400 & 235 & 985 & 1150 & 20 & 20,290 & 2060 \\
$248-12-5$ & $396.4-396.5$ & 10,200 & 235 & 1075 & 1300 & 20 & 20,140 & 2310 \\
$248-14-3$ & $411.4-411.5$ & 10,000 & 190 & 870 & 1650 & 20 & 20,000 & 2170 \\
$249-1-5$ & $7.4-7.5$ & 10,500 & 430 & 1280 & 500 & 15 & 19,790 & 2680 \\
$249-2-2$ & $10.9-11.0$ & 10,900 & 445 & 1315 & 500 & 20 & 20,140 & 2380 \\
$249-4-5$ & $34.4-34.5$ & 10,900 & 430 & 1310 & 575 & 30 & 20,290 & 2520 \\
$249-6-5$ & $53.4-53.5$ & 10,800 & 425 & 1280 & 575 & 30 & 20,140 & 2470 \\
$249-8-5$ & $72.4-72.5$ & 10,700 & 415 & 1270 & 575 & 35 & 20,530 & 2390 \\
$249-10-5$ & $91.4-91.5$ & 10,700 & 415 & 1235 & 575 & 40 & 20,470 & 2300 \\
$249-12-5$ & $110.4-110.5$ & 10,400 & 375 & 1240 & 575 & 40 & 20,070 & 2330 \\
$249-14-5$ & $138.4-138.5$ & 10,600 & 385 & 1205 & 650 & 45 & 20,640 & 2310 \\
$249-15-5$ & $157.4-157.5$ & 10,800 & 325 & 1180 & 775 & 40 & 20,000 & 2260 \\
$249-16-1$ & $170.4-170.5$ & 10,800 & 305 & 1170 & 850 & 35 & 21,360 & 2100 \\
$249-17-5$ & $185.4-185.5$ & & & & & & & \\
$249-19-3$ & $222.4-222.5$ & 10,600 & 305 & 1155 & 1000 & 30 & 20,000 & 2150 \\
$249-21-5$ & $263.4-263.5$ & 10,600 & 285 & 1135 & 1150 & 25 & 20,710 & 2060 \\
$249-23-3$ & $288.4-288.5$ & 10,300 & 240 & 930 & 1725 & 25 & 21,000 & 1670 \\
\hline
\end{tabular}

${ }^{\mathrm{a}}$ Sample of interstitial water lost by transport.

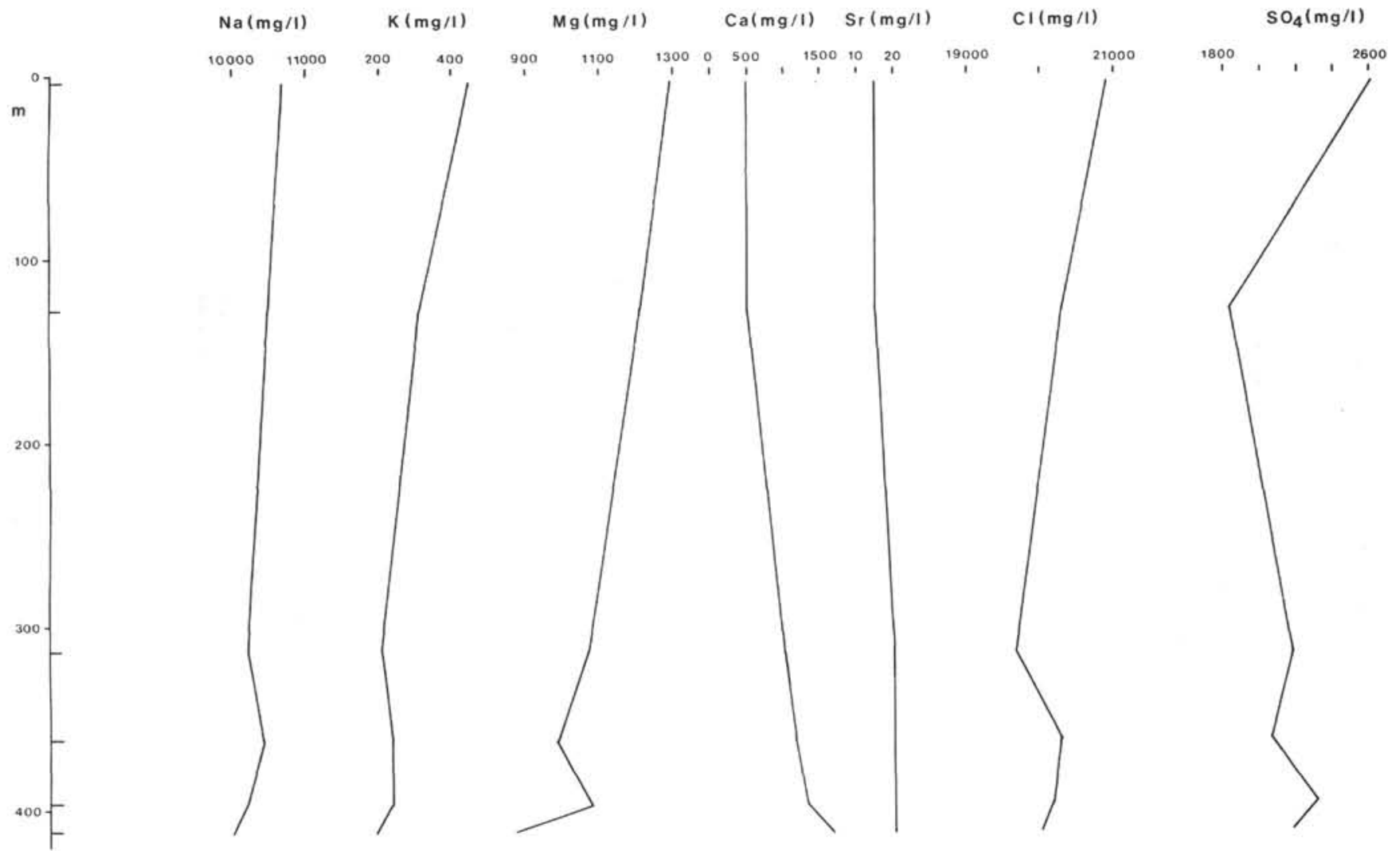

Figure 5. Interstitial water chemistry, Site 248.

the chemistries. Possibly, the original volcanic sediment was impoverished in these elements and that did not change during diagenesis because the newly formed minerals still are impoverished in all of those trace elements except $\mathrm{Mg}$. The fact that even $\mathrm{Mg}$ is depleted, points to the prevalence of clinoptilolite over montmorillonite and palygorskite.

\section{Carbonate}

Carbonate contents are presented in Table 6 and Figure 7. Unit II shows a decrease in $\mathrm{Sr}$ and $\mathrm{Fe}$ and an increase in $\mathrm{Mg}$ and $\mathrm{Mn}$. The strontium may have been expelled from the crystal lattice during the aragonite-calcite conversion or 

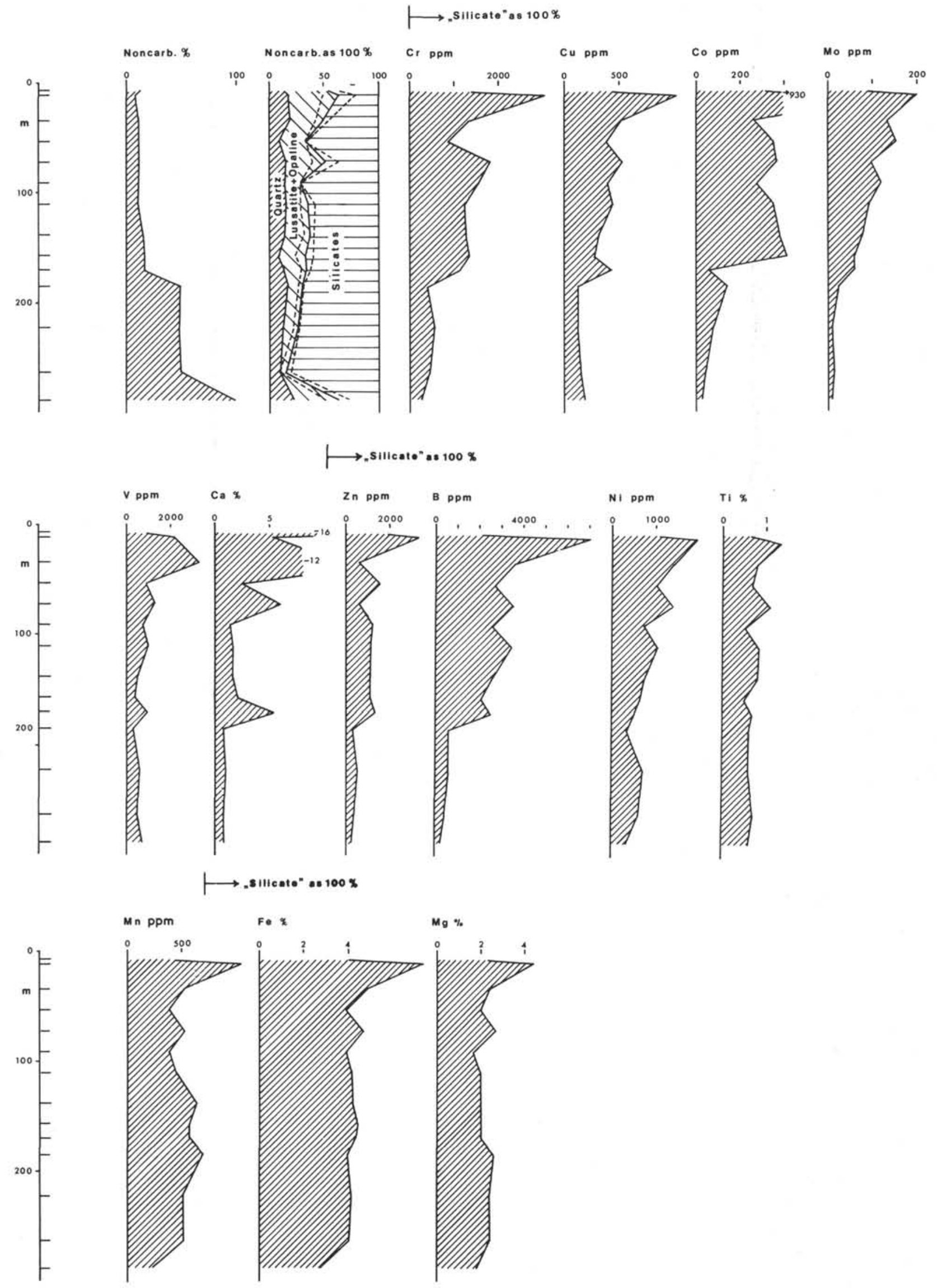

Figure 6. Noncarbonate chemistry, Site 249. 


\section{$\mathrm{CaCO}_{3} \%$}

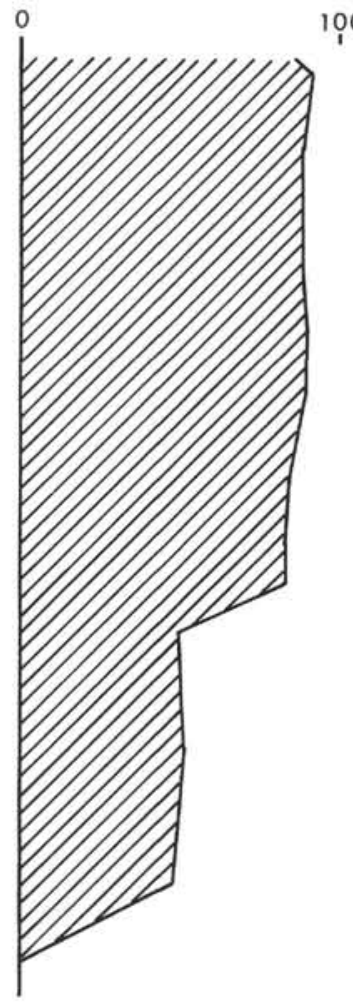

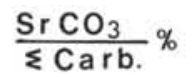
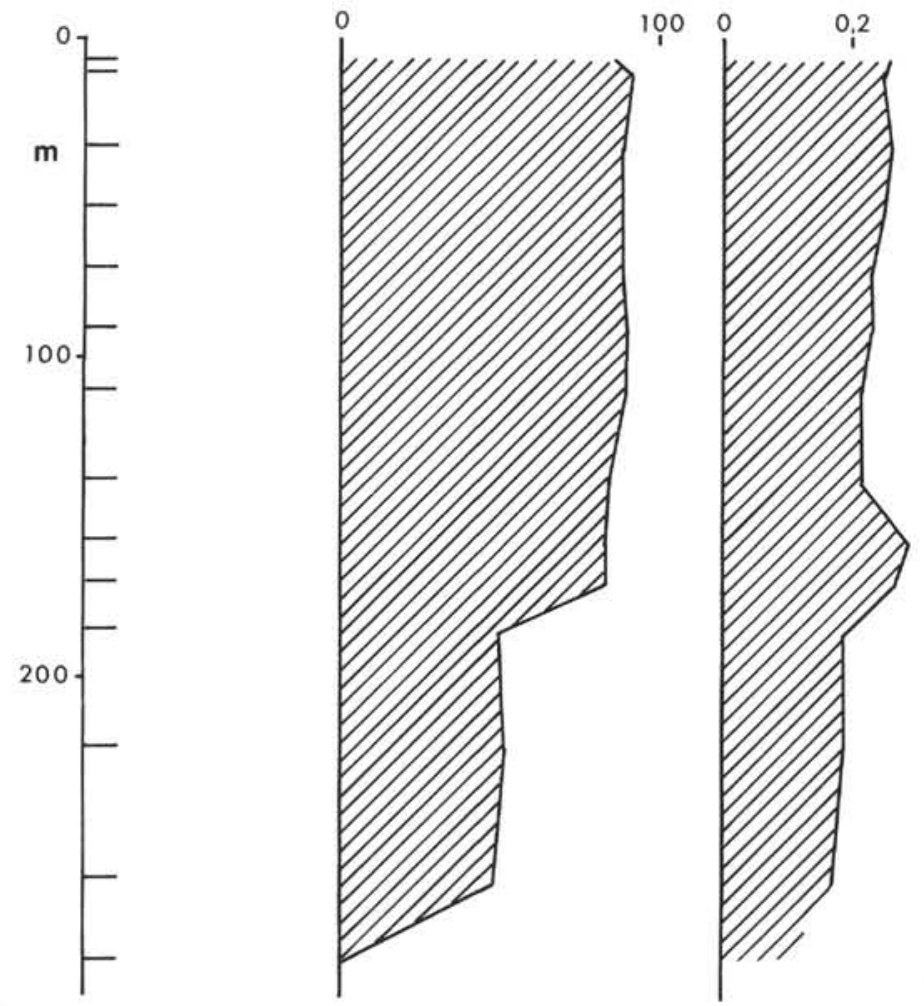
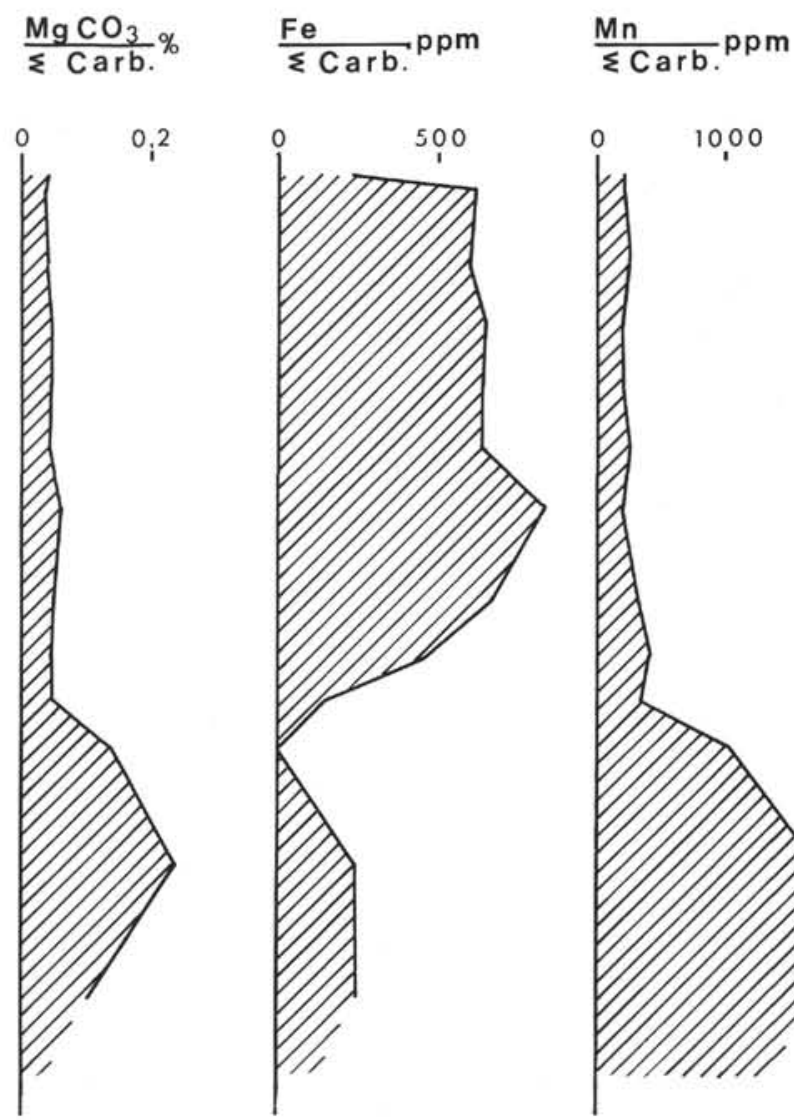

Figure 7. Carbonate chemistry, Site 249.

possibly during calcite-calcite recrystallization, as mentioned above. The $\mathrm{Fe}$ and $\mathrm{Mn}$ contents may not be related to the carbonate lattice; rather, they probably are related to the solubility of $\mathrm{Fe} / \mathrm{Mn}$ oxides (amorphous) that occur in the noncarbonate fraction and were taken into solution during treatment with $0.2 \mathrm{~N} \mathrm{HCOOH}$.

Carbonate contents in Unit III are not discussed because of the very small amount of carbonate $(0.8 \%)$ in the sample. Although the results are reproducible, it is believed that much of the high ion contents is the result of treatment by the strong acid, which would be expected to take ions into solution from some of the noncarbonate fraction.

\section{Interstitial Water}

Results from studies of interstitial water at Site 249 are presented in Table 7 and Figure $8 . \mathrm{K}$ and $\mathrm{Mg}$ show a somewhat regular depletion with depth, whereas Ca content is enriched with depth. Sr is first enriched (to about 130 $\mathrm{m}$ ), and then depleted. $\mathrm{Cl}$ and $\mathrm{Na}$ show no regular relationship with depth in this study. The decrease in $\mathrm{Mg}$ might be related either to the formation of dolomite with depth or to the formation of palygorskite; however, any specific conclusions must await further studies. The depletion of $\mathrm{Sr}$ (below $130 \mathrm{~m}$ ) may be the result of its adsorption on clay minerals, similar to that found by Flügel and Wedepohl (1967). Clay content does increase, which makes this explanation plausible.
In Unit III, $\mathrm{Na}, \mathrm{K}, \mathrm{Mg}$, and $\mathrm{SO}_{4}$ are depleted and $\mathrm{Ca}$ is enriched. Possibly, the mineral clinoptilolite has affected the relative concentrations of the cations. X-ray analysis of a sample (Matti et al., this volume), near the one studied for this report, shows 20 percent clinoptilolite in the bulk analysis.

\section{CONCLUSIONS}

In general, there are close relationships between changes in sediment and interstitial water chemistries relative to depth at Sites 248 and 249. Chemistries of sediments are mostly related to the original nature of the sediment, that is, terrigenous, biogenous, or volcanic. However, the chemistry of interstitial waters mostly depends on postdepositional diagenetic changes that occur in the sediment.

In the case of Sites 248 and 249 , a terrigenous origin is indicated mineralogically by enrichment of heavy minerals and chemically by the enrichment of $\mathrm{Ti}$ and $\mathrm{Cr}$ (magnetite?). A volcanic origin is indicated by an enrichment of $\mathrm{Mg}$ in montmorillonite and palygorskite, and a biogenic origin, by abundant calcium carbonate.

Carbonate diagenesis and conversion affect both the chemistry of carbonates as well as the chemistry of the interstitial waters. The enrichment of $\mathrm{Mg}$ in carbonate after the formation of dolomite depletes the $\mathrm{Mg}$ content of the interstitial water. Conversion of aragonite to calcite or (less probably) calcite (formed by organisms) to calcite conversions, transfers $\mathrm{Sr}$ from the carbonate into the 


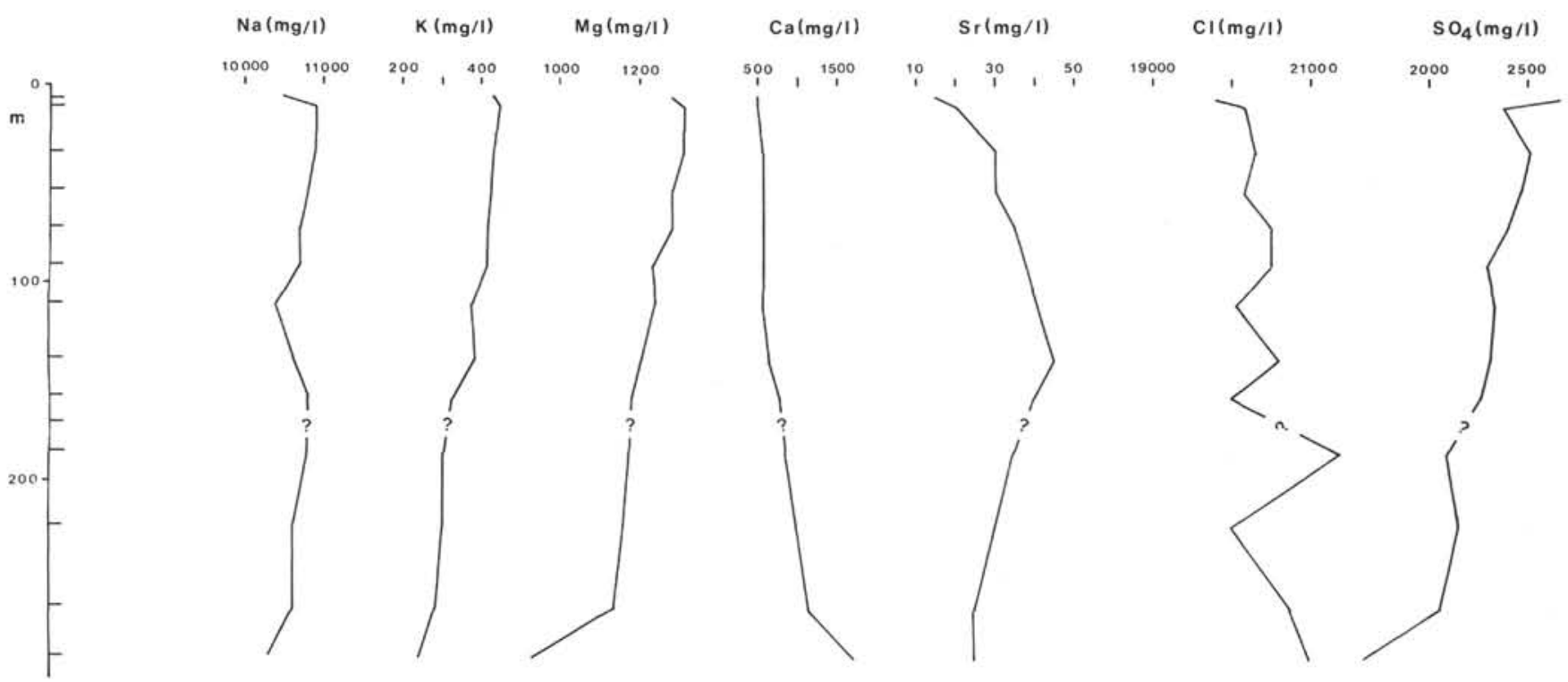

Figure 8. Interstitial water chemistry, Site 249.

interstitial water. In the noncarbonate fraction of the sediment, the devitrification of volcanic material and diagenetic formation of clinoptilolite, palygorskite, and montmorillonite seem to have a strong influence on the chemistry of the interstitial waters. Clinoptilolite can adsorb different cations, whereas montmorillonite and palygorskite can fix $\mathrm{Mg}$ in their crystal lattices.

Eh conditions can change the trace metal contents of the sediments. For example, the sulfides which crystallize in a reducing environment can incorporate $\mathrm{Zn}, \mathrm{Cu}, \mathrm{Co}$, Mo, and $\mathrm{Ni}$ into their crystal lattices. Changes of Eh also can cause the post-depositional mobility of Mn without activating (moving) trace elements such as $\mathrm{Ni}$ and $\mathrm{Co}$, which are generally hosted in Mn-oxides.

It can be expected that all the above mentioned processes influence the metal concentrations in interstitial waters. Unfortunately, our methods of determining such small quantities of these metals as appear in interstitial waters are not yet sufficiently sensitive.

Site 248 shows several changes with depth, both in noncarbonate and interstitial water chemistries, which are partly caused by the reactions mentioned above. The noncarbonate fraction of Unit II shows depletions in $\mathrm{Cr}$, $\mathrm{Co}, \mathrm{Ca}, \mathrm{Mn}, \mathrm{Fe}, \mathrm{B}$, and $\mathrm{Ni}$ and an increase in $\mathrm{Mg}$. The depletions may be related to the original nature of the sediment and the increase in $\mathrm{Mg}$ probably is related to the high palygorskite content. In Unit III, there is an increase in $\mathrm{Fe}$ and $\mathrm{Mn}$, although there is no parallel increase in $\mathrm{Cu}, \mathrm{Co}$, $\mathrm{Mo}$, and $\mathrm{Ni}$ as expected. Possibly, the relative mobility of the ions have a strong affect on the final concentrations. Interstitial water chemistries in part are related to the reduction of sulfate, the formation of palygorskite, the formation of dolomite, the aragonite-calcite conversion, and to the crystallization of clinoptilolite.
Changes with depth at Site 249 are somewhat similar to those at Site 248. In the noncarbonate fraction of Unit I, there is an enrichment in $\mathrm{Cu}, \mathrm{Co}, \mathrm{Mo}, \mathrm{Zn}$, and $\mathrm{Ni}$ which might be related to the formation of sulfides. Boron enrichment may be the result of adsorption on clay minerals and $\mathrm{Ca}$ content might mirror the plagioclase feldspar concentration. In Unit II, the magnesium probably is related to the dolomite and/or palygorskite contents. Unit III is depleted in many of the trace elements, possibly the result of the original volcanic nature of the deposit. The formation of clinoptilolite could also account for these relative depletions in the noncarbonate parts of the sediment. Interstitial water chemistries show changes related to the formation of dolomite, palygorskite, and clinoptilolite and possibly, the depletion of $\mathrm{Sr}$ is related to its adsorption in the clay mineral lattices.

\section{REFERENCES}

Bonatti, E., Fisher, D. E., Joensuu, O., and Rydell, H. S., 1971. Postdepositional mobility of some transition elements, phosphorous, uranium and thorium in deep sea sediments: Geochim. Cosmochim. Acta, v. 35, p. 189-201.

Flügel, H. W. and Wedepohl, K. H., 1967. DieVerteilung des Strontiums in oberjurassischen Karbonatgesteinen der Nördlichen Kalkalpen: Contrib. Min. Petrol., v. 14, p. 229-249.

Harder, H., 1961. Einbau des Bors in detritische Tonminerale: Geochim. Cosmochim. Acta, v. 21, p. 284-294.

Marchig, V., in press. ZurGeochemie rezenter Sedimente aus den Indischen Ozean II: "Meteor"-Forsch. Engeb. Reihe C. 